\title{
The Role of Subaquatic Springs in the Formation of Flow, Temperature and Chemical Composition of River Water in the Reserve
}

\author{
Sergey Vaganov ${ }^{1 *}$, Sergey Blinov ${ }^{1}$, Pavel Belkin ${ }^{1}$, Roman Perevoshchikov ${ }^{1}$ \\ 1 Perm State University, Bukireva St. 15, 614990 Perm, Russia \\ * Corresponding author's e-mail:vaganov_ss@mail.ru
}

\begin{abstract}
A study of the effect of subaquatic discharge of karst groundwater sources on the composition of the Vishera River, the largest tributary of the Kama River, was carried out. The study was carried out on the territory of the State Nature Reserve "Vishersky" and included the determination of the flow rate, temperature as well as chemical composition of natural waters. Six zones of karst groundwater discharge and their influence on the water regime of the Vishera river were studied in detail. It was shown that subaquatic sources in the places of their discharge, forming up to $36 \%$ of the river flow, significantly affect the temperature regime. A significant part of dissolved substances, primarily calcium ions and hydrocarbonate ions, as well as some trace elements ( $\mathrm{Li}, \mathrm{Sr}, \mathrm{V}, \mathrm{Cr}$ ) enter the Vishery river with karst waters. The results of the study show that monitoring the composition and properties of groundwater discharged covertly in the river channel is an important part of the monitoring of water bodies of both protected and developed areas.
\end{abstract}

Keywords: karst, groundwater, surface water, subaquatic springs, chemical composition of groundwater, chemical composition of surface water, river flow formation, temperature regime, nature reserves.

\section{INTRODUCTION}

Discharge of underground karst water is often in the form of underwater springs from the bottoms of rivers, lakes and seas [Maksimovich, 1961, Wirth et al., 2020; Cantú Medina et al., 2021]. It can lead to significant changes in the flow, temperature and chemical composition of river water, a decrease in dissolved oxygen and other parameters [Afgane et al., 2021; Mustafa et al., 2016; Gonneea et al., 2014]. In urban, industrial and agricultural areas, subaquatic discharge can lead to hidden pollution of rivers and lakes [Vaganov, 2017; Xilong et al, 2021; Stevanović et al., 2022]. This can significantly affect both the surface water bodies themselves and the state of the biotic components of the environment [Tamborski et al., 2020; Schubert et al., 2014]. In this regard, the study of subaquatic groundwater discharge is an important hydrogeological, hydrological and geo-environmental task [Blinov et al., 2004, Davybida et al., 2018; Pratama et al., 2021].

The mouths of subaquatic springs are under water for most or all of the year and are hidden from the eyes of observers by the water column. In this regard, the search and study of subaquatic groundwater sources is a complex task requiring the use of both conventional and special research methods [Naoura et al., 2021; Stevanović, 2019; Savatier et al., 2021]. As an example of the influence of subaquatic karst water discharge on the flow and composition of river water, this article examined the results of research conducted by Permian University staff in the territory of the Vischersky Reserve (Western Urals).

\section{STUDY AREA}

The system of state nature reserves in Russia was created in order to preserve and study the 
natural course of processes and phenomena of inanimate and living nature. At the moment, there are more than 100 nature reserves in the country, which are one of the types of specially protected natural areas.

The Vishersky Reserve is located in the northeastern part of the Perm Region. The area of the protected area is 2412 square kilometers (Figure 1). There are no settlements on the territory of the reserve; the employees of the reserve live in small cordons for control functions and scientific observations.

The geological section of the reserve is represented by Riphean and Paleozoic rocks. A significant area of the Vishersky Reserve is occupied by surface outcrops of karsted carbonate rocks - limestone, dolomite, marble. The karst processes are especially active in the river valleys, which are weakened zones of fractured rocks. These zones are characterized by a large number of karst manifestations. The rivers are often absorbed by karst sinkholes and in some parts have only an underground flow, reappearing downstream in the form of powerful karst springs. Many karst springs on the territory of the Reserve are discharged subaqually, from the bottoms of rivers and karst lakes.

In this regard, the purpose of this work was to find and study subaquatic karst sources on the territory of the "Vishersky" reserve, as well as to study their influence on the flow rate, temperature and composition of river water.

\section{METHODS}

The search for subaquatic karst sources was carried out using a specially developed set of methods in several stages. The task of the initial stage was to identify the areas promising for the search of subaquatic sources. For this purpose, the analysis of topographic, geological and hydrogeological maps, as well as space and aerial photos was carried out before the beginning of expedition works. The search signs for the identification of promising areas were: the location of rivers and lakes within the limits of karst rock outcrops; borders of karst and insoluble rocks; detection of chains and fields of karst sinkholes; detection of lakes in the river sources; detection of non-freezing areas of water bodies on the winter images, etc. The data from previous studies were also analyzed [Blinov et al. 2004, 2008].

The expedition stage included prospecting works in the promising areas identified at the previous stage. Field expedition works on searching and research of subaquatic karst sources on the territory of the "Vishersky" reserve were carried out in July 2018. The section of the Vishera river from the mouth of the Niols river to a point located $2 \mathrm{~km}$ downstream the mouth of the Lypya river, a total length of $45 \mathrm{~km}$ was surveyed (Figure 2).

The survey was carried out by rafting down the river on a twin-gauged catamaran. The main search method involved thermometric and conductometric observations. The method was based

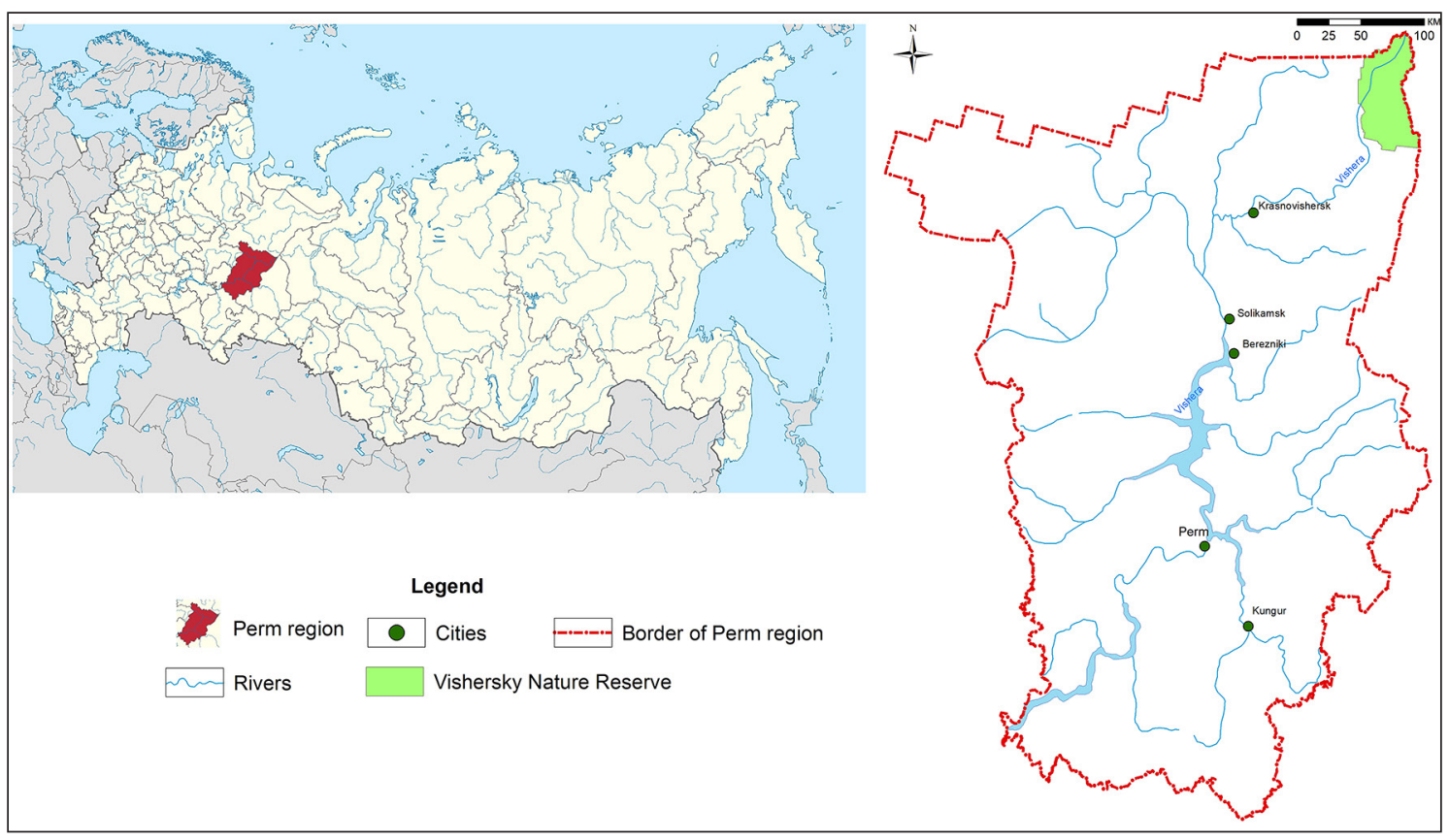

Figure 1. Location of the Vishersky Reserve 


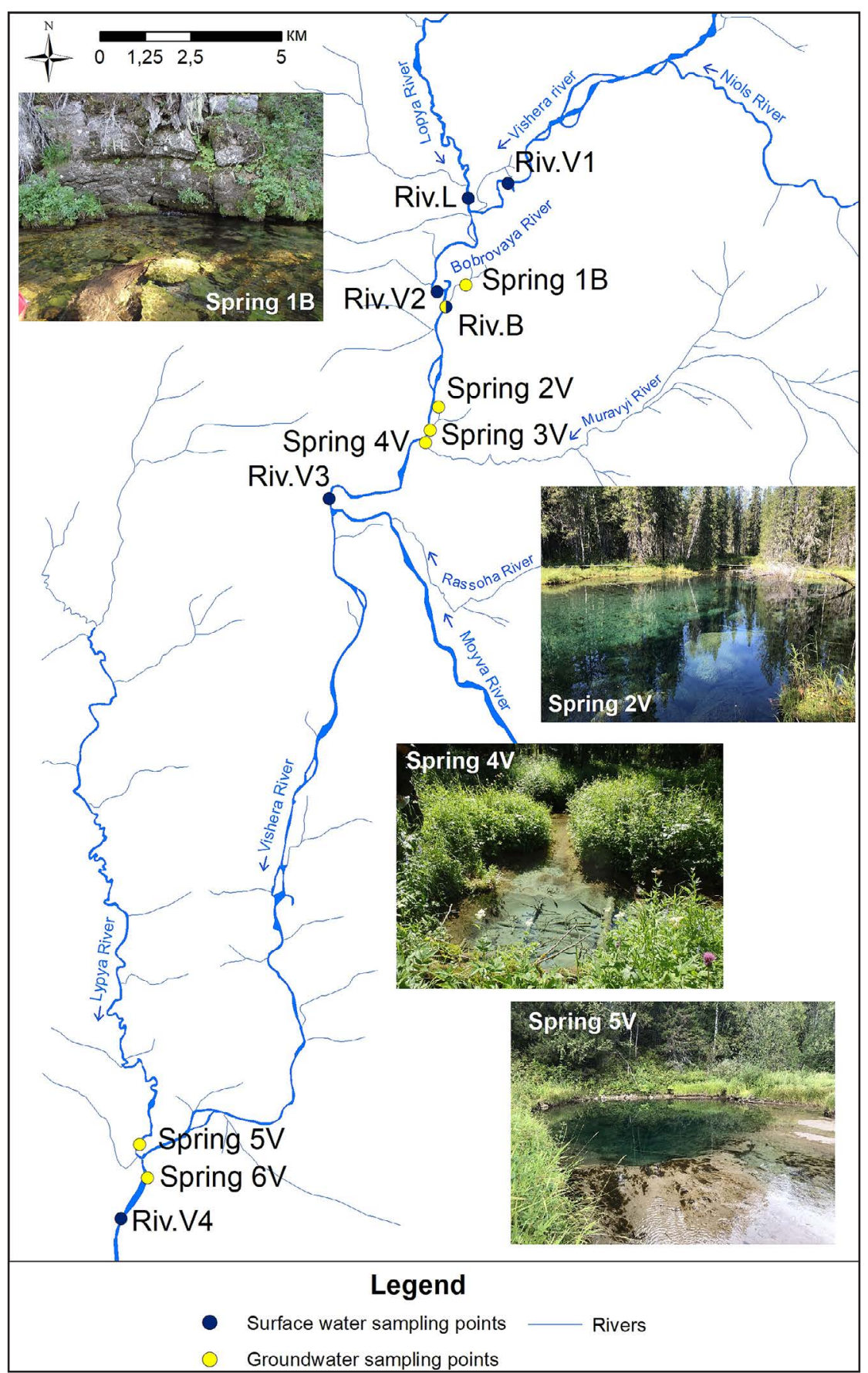

Figure 2. Schematic diagram of the study area

on the significant difference between the temperature and total salinity of the river water, and the groundwater of the karst springs being discharged. For this purpose, the search equipment (field instruments "Expert") was placed on the vessel, equipped with probes for determination of water temperature, specific electric conductivity (SCE), $\mathrm{pH}$ indicator in situ, at a depth of up to $3 \mathrm{~m}$.

Measurements were taken during rafting along the river, every $50 \mathrm{~m}$. When anomalous values of temperature and SCE were detected, additional measurements were carried out with densification of the observation network, up to the visual detection of a subaquatic source. The study of the subaquatic spring included visual description and underwater photography of the spring mouth, measurement of flow and water temperature, and water sampling to determine the chemical composition.

The discharge of surface watercourses and groundwater sources was measured with a hydrometric vane. The water balance calculations 
were conducted to determine the discharge of subaquatic sources, if necessary. Water sampling was carried out by a deep sampling device directly at the source mouth. Laboratory studies included total and trace element analysis of water performed in the accredited laboratories of Perm University. Cations and anions were determined by capillary electrophoresis (capillary electrophoresis system "KAPEL-105M") as well as using the titrimetric method. The trace element composition of water was determined by inductively coupled plasma mass spectrometric analysis ICP-MS (Aurora M90, Bruker).

\section{RESULTS AND DISCUSSION}

A total of 5 large subaquatic karst springs were described during the works, which are discharged into the Vishera river channel (Spring $2 \mathrm{~V}-6 \mathrm{~V})$. At the same time, the chemical composition, temperature and water flow were investigated in the Vishera River (Riv. V1-V3), as well as at the mouth of its large tributary, the Lopya River (Riv.L).

The Bobrovaya River is an important object of study. The flow of this river is almost entirely formed by numerous karstic groundwater sources discharging from a subhorizontal fissure in a rock outcrop of carbonate rocks (Figure 2, Photo Spring 1B). As part of the described work, a study of the Bobrovaya River at its mouth (Riv.B) was carried out, and one of the subaquatic springs that form the river flow was investigated (Spring 1B).

\section{Water discharge of the Vishera River, tributaries and springs}

Measurements of the river and groundwater flow rates were conducted during the summer low-water period. Atmospheric precipitation was absent during measurements from June $22^{\text {nd }}$ to $25^{\text {th }}$, 2018. The measured discharges and water temperature of rivers and groundwater sources are shown in Table 1. At the initial point of the study site, which is located upstream of the surface area of karsted carbonate rocks, the flow rate of the Vishera River was $3.2 \mathrm{~m} / \mathrm{s} ; 4 \mathrm{~km}$ downstream, the Lopya River flows into the Vishera River, the flow rate of which at the mouth during the period of measurements was $0.9 \mathrm{~m}^{3} / \mathrm{s}$.

Thus, the Lopja river, which on a fairly long stretch has only groundwater flow, and the chemical composition of water which is formed, inter alia, due to dissolution of carbonate rocks, contributes almost $22 \%$ to the formation of the flow of the Vishera river. The next large tributary of the Vishera River is the Bobrovaya River, which is fed almost entirely by numerous karst groundwater sources, discharging from a subhorizontal fissure in the rock outcrop of carbonate rocks. Throughout most of the year, the fissure is located below the water level of the Bobrovaya River and the discharge occurs subaqually (Figure 3 (A)). The flow rate of the Bobrovaya River at the mouth is $3.1 \mathrm{~m}^{3} / \mathrm{sec}$, and that of the Vyshera River before the confluence is $5.4 \mathrm{~m}^{3} / \mathrm{s}$. The contribution of subaquatic karst sources to the total discharge of the Vishera river in this area is $36 \%$.

Table 1. Measured flow rates and temperatures of rivers and groundwater sources

\begin{tabular}{|c|c|l|c|c|}
\hline $\begin{array}{c}\text { Measurement } \\
\text { site }\end{array}$ & $\begin{array}{c}\text { Distance } \\
\text { from the initial } \\
\text { point, km }\end{array}$ & \multicolumn{1}{|c|}{ Description } & $\begin{array}{c}\text { Flow rate } \\
\text { water, L/s }\end{array}$ & $\begin{array}{c}\text { Water } \\
\text { temperature, } \\
{ }^{\circ} \mathrm{C}\end{array}$ \\
\hline Riv.V1 & 0.00 & Vishera River, 4 km upstream of the mouth of the Lopya River & 3215 & 16 \\
\hline Riv.L & 4.00 & Lopya River, the mouth & 929 & 16 \\
\hline Riv.V2 & 6.96 & Vishera River, upstream of the mouth of the Bobrovaya River & 5425 & 13 \\
\hline Riv.B & 7.75 & Bobrovaya River, the mouth & 3114 & 6 \\
\hline Spring 1B & & $\begin{array}{l}\text { Spring 1 (400 m upstream of the mouth of the Bobrovaya } \\
\text { River) }\end{array}$ & 10 & 5 \\
\hline Spring 2V & 11.15 & Spring 2 (900 m upstream of the Muravy River mouth) & 829 & 5 \\
\hline Spring 3V & 11.35 & Spring 3 (450 m upstream of the Muravy River mouth) & 298 & 5 \\
\hline Spring 4V & 11.35 & Spring 4 (200 m upstream of the Muravy River mouth) & 188 & 5 \\
\hline Riv.V3 & 15.62 & Vishera, upstream of the mouth of the Moyva River & 16420 & 12.3 \\
\hline Spring 5V & 39.34 & Spring 5 (300 m upstream of the mouth of the Lypya River) & 434 & 5 \\
\hline Spring 6V & 40.45 & $\begin{array}{l}\text { Spring 6 (900 m downstream from the mouth of the Lypya } \\
\text { River) }\end{array}$ & 10 & 5 \\
\hline Riv.V4 & 44.61 & Vishera River, downstream the mouth of the Lypya River & - & 14.2 \\
\hline
\end{tabular}




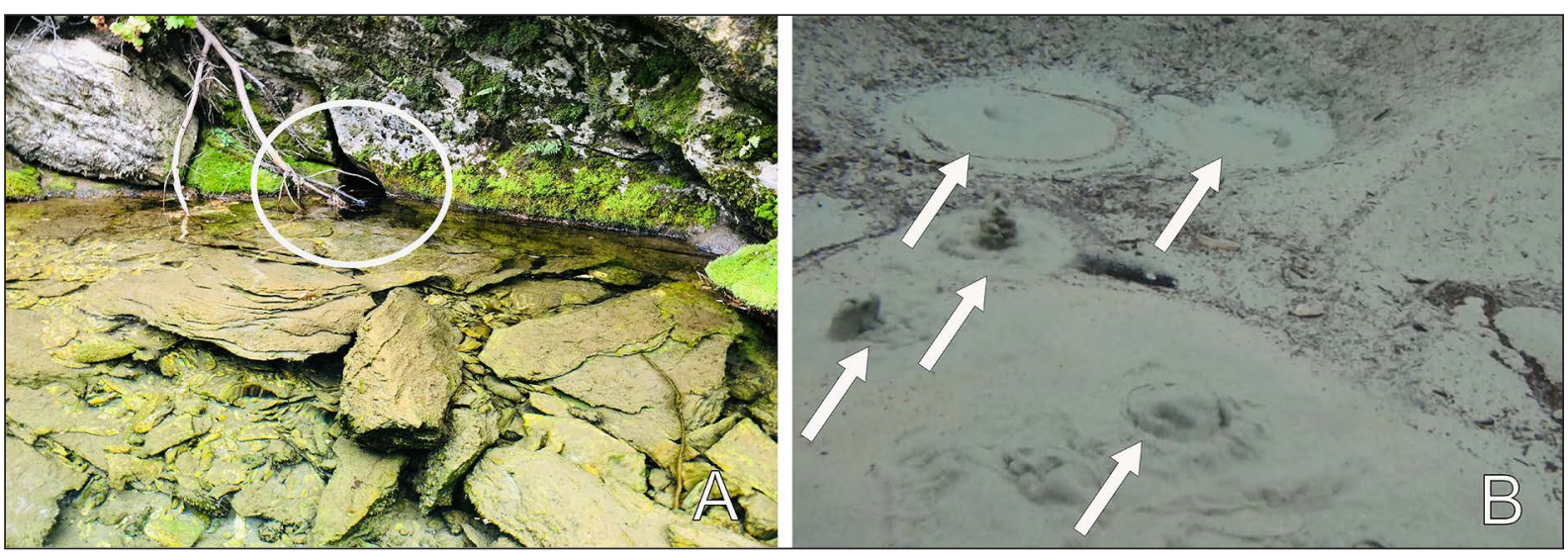

Figure 3. (A) Discharge from a subhorizontal fissure (Spring 1B); (B) Discharge from the bottom, through the alluvium layer (Spring 4V)

Downstream of the Vishera River, several large karst springs near the mouth of the Muravy River participate in the formation of water flow (Figure 3 (B)). They are discharged subaqually into the karst lakes formed by them, the flow from which enters the Vishera River. The total discharge of these springs is $1.3 \mathrm{~m}^{3} / \mathrm{s}$. Another large subaquatic karst spring is located at the mouth of the Sukhaya Lypya River, which in a large area has only underground flow. Here, the discharge comes from the bottom of the karst sinkhole, forming a lake, the water from which overflows into the Lypya river with a flow rate of $0.4 \mathrm{~m}^{3} / \mathrm{s}$ and further enters the Vishera river. Measurement of the water flow in the closing section (Riv.V4) under the conditions of the work was impossible due to the significant depth and velocity of the river flow.

\section{Water temperature of the Vishera River, tributaries and springs}

The water temperature in the Vishera River, like in other rivers, experiences seasonal and diurnal fluctuations caused by precipitation, changes in atmospheric air temperature, and other factors. The measurements of surface water temperature of the Vishera River, its tributaries and subaquatic springs were carried out during the summer lowwater period, in the absence of rain with daytime temperatures of $20-25^{\circ} \mathrm{C}$ and nighttime temperatures of $10-15^{\circ} \mathrm{C}$. In the initial point of the study site, the water temperature in the river during the day was $16^{\circ} \mathrm{C}$ (Table 1 ). The water temperature of subaquatic karst springs is stable and equal to $5^{\circ} \mathrm{C}$. At the sections of the Vishera River downstream of the discharge of subaquatic springs, the water temperature decreased sharply by several degrees due to mixing with cold groundwater. At long sections downstream, there was a gradual recovery of river water temperature.

\section{Chemical composition of water of the Vishera river, tributaries and springs}

Hydrogen index of water of the Vishera river in the initial point of the studied area (upper streams of the Vishera river) has a neutral value (7.0-7.4). Downstream of the places of discharge of subaquatic karst sources, the $\mathrm{pH}$ values in the river water rise to 7.6 , and at the end of the study area - to 8.0 (Figure 4). Thus, the general regularity of the growth of the river water $\mathrm{pH}$ index of the Vishera River was revealed. Vyshera River, caused by the inflow of karst source waters. This is due to the fact that a major role in the formation of the chemical composition of groundwater of karst massifs is played by the dissolution of carbonate rocks. As a result of dissolution of carbonate ions, the water of subaquatic springs becomes slightly alkaline, with the $\mathrm{pH}$ values of 7.9-8.2.

The water of the Vishera River throughout the entire study area is ultra-fresh, with salinity less than $100 \mathrm{mg} / \mathrm{L}$ (Table 2). Water composition is hydrocarbonate-calcium. There is a gradual increase in water salinity from the beginning of the studied area to its end from 20 to $60 \mathrm{mg} / \mathrm{L}$. An increase in water salinity occurs mainly due to an increase in bicarbonate ion and calcium ion (Figure 5); to a much lesser extent, it is caused by an increase in sulfate ion, magnesium and sodium ions.

Chloride ion and potassium ion appear in tangible amounts in the water of the Vishera River only downstream of the mouth of the Lypya River (Riv.V4). It should be noted that the permanent residence of the reserve's employees is located 


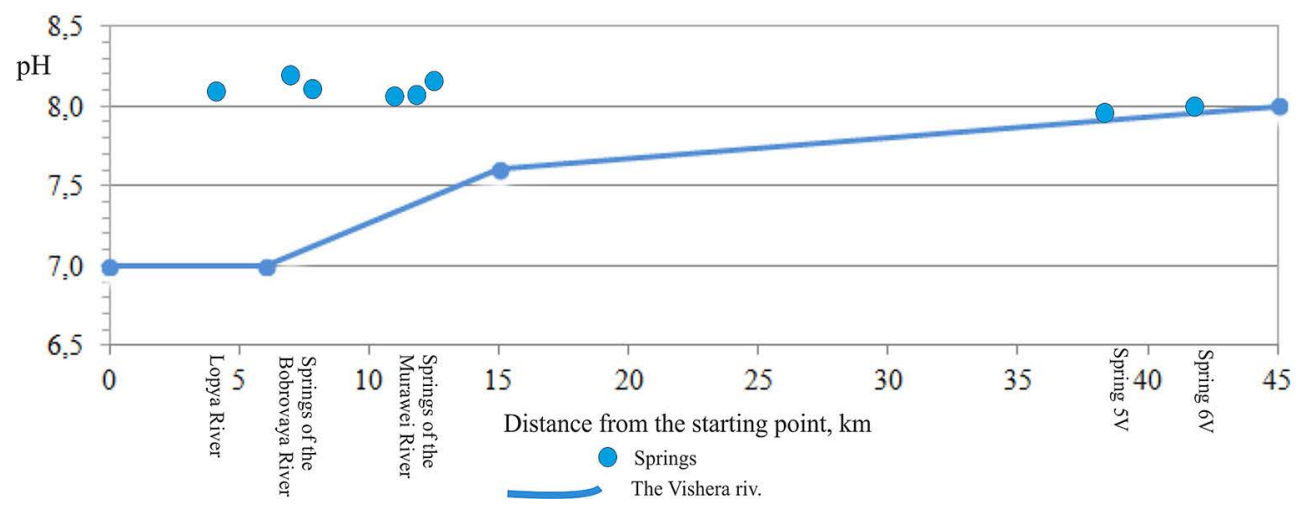

Figure 4. The $\mathrm{pH}$ of water of the Vishera River and Springs

in the mouth of the Lypya River. There are no places of permanent residence upstream of this section along the river.

The salinity of water of subaquatic karst sources is higher than the salinity of river water and is $100-128 \mathrm{mg} / \mathrm{L}$ (Table 2). The composition of water is calcium-hydrocarbonate, with $\mathrm{HCO}_{3}{ }^{-}$and $\mathrm{Ca}^{2+}$ accounting for more than $90 \%$ of the total mineralization. Sulfates, nitrates, magnesium and sodium ions are present in small amounts. Chloride ions and potassium were not detected by chemical analysis.

\section{Trace element composition of water of the Vishera River, tributaries and springs}

The study of the trace element composition of groundwater and surface water (Table 3) allowed distinguishing three groups of elements.

The first group includes the elements the content of which in the groundwater of karst sources is significantly higher than in the water of the Vishera River. Such elements include alkaline earth metals $\mathrm{Li}$ and $\mathrm{Sr}$, which along with $\mathrm{Ca}$ and $\mathrm{Mg}$ are present in increased concentrations in carbonate rocks [Sklyarov, 2001]. An expressive example of elements from this group is strontium. In the water of subaquatic karst springs the strontium content is 1.5-2 times higher than in the water of the Vishera river. As a result, of the fact that the feeding of the river is largely due to subaquatic karst water discharge, the concentration of elements of this group in the river water increases downstream (Figure 6). The metals V and $\mathrm{Cr}$ also belong to this group.

The second group includes elements the content of which in groundwater is much lower than in the river water. These elements include $\mathrm{Y}, \mathrm{Zr}$ and Ce (Table 3, Figure 7). The concentration of these elements in the river water decreases downstream of the Vishera river due to a significant inflow of subaquatic spring waters.

The third group includes the elements the content of which in groundwater and surface water is approximately the same or changes in concentration do not have clear relationships.

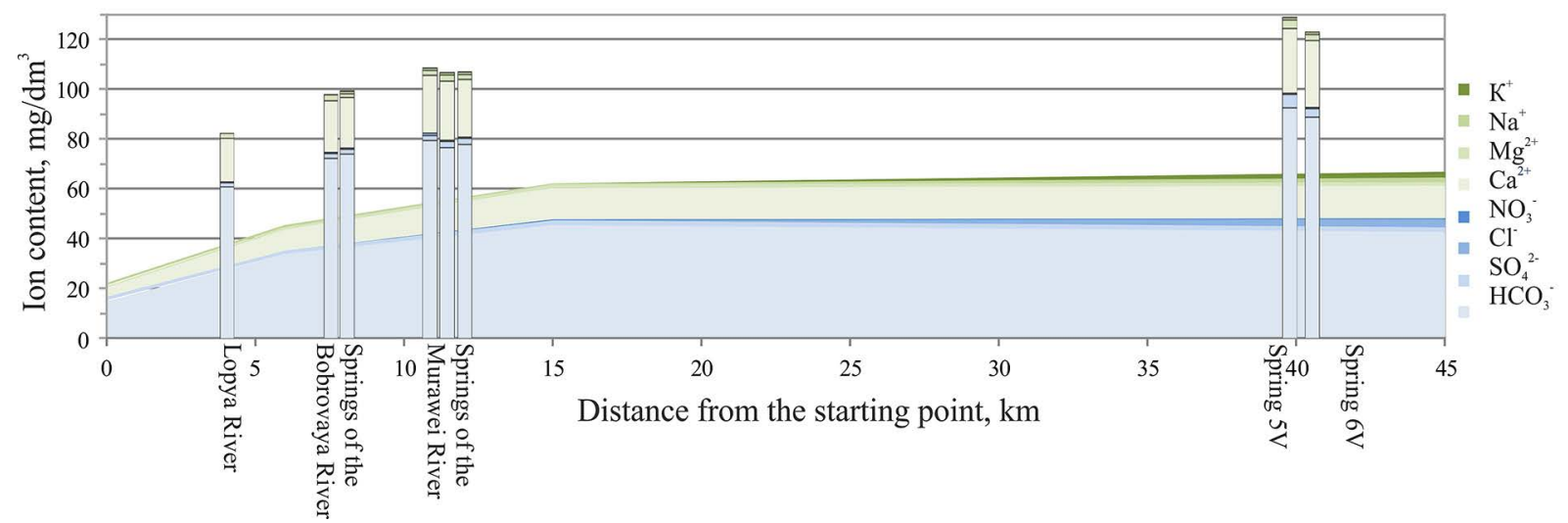

Figure 5. Chemical composition of water of the Vishera river and karst springs 
Table 2. Chemical composition of water of the Vishera river and karst waters (summer low water period), $\mathrm{mg} / \mathrm{L}$

\begin{tabular}{|c|c|c|c|c|c|c|c|c|c|c|c|}
\hline Sampling point & $\mathrm{pH}$ & $\mathrm{HCO}_{3}^{-}$ & $\mathrm{SO}_{4}^{2-}$ & $\mathrm{Cl}^{-}$ & $\mathrm{NO}_{3}^{-}$ & $\mathrm{NO}_{2}^{-}$ & $\mathrm{Ca}^{2+}$ & $\mathrm{Mg}^{2+}$ & $\mathrm{Na}^{+}$ & $\mathrm{K}^{+}$ & Mineralization \\
\hline Riv.V1 & 7.4 & 15.0 & 1.41 & $\mathrm{~b} / \mathrm{d}$ & $\mathrm{b} / \mathrm{d}$ & $\mathrm{b} / \mathrm{d}$ & 3.9 & 0.76 & 0.99 & $\mathrm{~b} / \mathrm{d}$ & 22.0 \\
\hline Riv.V2 & 7.0 & 33.8 & 1.52 & $\mathrm{~b} / \mathrm{d}$ & $\mathrm{b} / \mathrm{d}$ & $\mathrm{b} / \mathrm{d}$ & 8.4 & 1.06 & 0.70 & $\mathrm{~b} / \mathrm{d}$ & 45.5 \\
\hline Riv.B & 8.1 & 74.1 & 2.0 & $\mathrm{~b} / \mathrm{d}$ & 0.59 & $\mathrm{~b} / \mathrm{d}$ & 20.4 & 1.78 & 0.8 & $\mathrm{~b} / \mathrm{d}$ & 99.6 \\
\hline Spring 1B & 8.2 & 72.8 & 2.0 & $\mathrm{~b} / \mathrm{d}$ & 0.49 & $\mathrm{~b} / \mathrm{d}$ & 21.1 & 2.12 & 0.9 & $\mathrm{~b} / \mathrm{d}$ & 99.4 \\
\hline Spring 2V & 8.0 & 78.2 & 2.2 & $\mathrm{~b} / \mathrm{d}$ & 0.59 & $\mathrm{~b} / \mathrm{d}$ & 23.1 & 1.99 & 0.9 & $\mathrm{~b} / \mathrm{d}$ & 106.9 \\
\hline Spring 3V & 8.0 & 75.4 & 2.2 & $\mathrm{~b} / \mathrm{d}$ & 0.60 & $\mathrm{~b} / \mathrm{d}$ & 23.5 & 2.21 & 0.9 & $\mathrm{~b} / \mathrm{d}$ & 104.7 \\
\hline Spring 4V & 8.1 & 76.9 & 2.2 & $\mathrm{~b} / \mathrm{d}$ & 0.58 & $\mathrm{~b} / \mathrm{d}$ & 22.8 & 2.12 & 0.7 & $\mathrm{~b} / \mathrm{d}$ & 105.3 \\
\hline Riv.V3 & 7.6 & 45.8 & 1.72 & $\mathrm{~b} / \mathrm{d}$ & 0.17 & $\mathrm{~b} / \mathrm{d}$ & 12.8 & 1.26 & 0.66 & $\mathrm{~b} / \mathrm{d}$ & 62.4 \\
\hline Spring 5V & 7.9 & 91.7 & 5.4 & $\mathrm{~b} / \mathrm{d}$ & 0.50 & $\mathrm{~b} / \mathrm{d}$ & 25.8 & 3.65 & 0.7 & $\mathrm{~b} / \mathrm{d}$ & 127.7 \\
\hline Spring 6V & 7.9 & 88.6 & 3.4 & $\mathrm{~b} / \mathrm{d}$ & 0.23 & $\mathrm{~b} / \mathrm{d}$ & 27.0 & 2.36 & 0.7 & $\mathrm{~b} / \mathrm{d}$ & 122.3 \\
\hline Riv.V4 & 8.0 & 42.8 & 2.03 & 3.2 & 0.28 & $\mathrm{~b} / \mathrm{d}$ & 12.9 & 1.43 & 1.99 & 2.3 & 67.0 \\
\hline
\end{tabular}

Note: 1) sampling points in the Vishera River are highlighted in bold; 2) b/d: below the detection limit; 3) sampling points in the table are arranged in the order of the route down the Vishera River.

Table 3. Trace element composition of water of the Vishera river and karst waters (summer low water period), $\mathrm{mg} / \mathrm{L}$

\begin{tabular}{|c|c|c|c|c|c|c|c|c|c|c|c|}
\hline Element & Riv.V1 & Riv.V2 & Riv.B & $\begin{array}{c}\text { Spring } \\
1 \mathrm{~B}\end{array}$ & $\begin{array}{c}\text { Spring } \\
2 \mathrm{~V}\end{array}$ & $\begin{array}{c}\text { Spring } \\
3 \mathrm{~V}\end{array}$ & $\begin{array}{c}\text { Spring } \\
4 \mathrm{~V}\end{array}$ & Riv.V3 & $\begin{array}{c}\text { Spring } \\
5 \mathrm{~V}\end{array}$ & $\begin{array}{c}\text { Spring } \\
6 \mathrm{~V} \\
\end{array}$ & Riv.V4 \\
\hline \multicolumn{12}{|c|}{ Group 1} \\
\hline $\mathrm{Li}$ & 0.04 & 0.08 & 0.13 & 0.12 & 0.10 & 0.09 & 0.07 & 0.12 & 0.95 & 0.49 & 0.12 \\
\hline $\mathrm{Sr}$ & 12.8 & 18.2 & 24.6 & 26.1 & 30.7 & 32.4 & 30.3 & 21.6 & 42.7 & 38.5 & 21.9 \\
\hline V & 0.81 & 1.14 & 1.69 & 1.37 & 1.45 & 1.82 & 1.58 & 1.11 & 1.82 & 1.71 & 1.36 \\
\hline $\mathrm{Cr}$ & 2.4 & 3.6 & 5.6 & 4.6 & 4.9 & 6.2 & 5.2 & 3.5 & 6.1 & 5.8 & 4.4 \\
\hline \multicolumn{12}{|c|}{ Group 2} \\
\hline $\mathrm{Al}$ & 16.20 & 8.20 & 0.40 & 1.40 & 0.60 & 0.10 & 1.10 & 11.20 & 7.10 & 10.80 & 8.80 \\
\hline $\mathrm{Ti}$ & 0.31 & 0.19 & 0.05 & 0.05 & 0.03 & 0.04 & 0.03 & 0.18 & 0.13 & 0.18 & 0.20 \\
\hline $\mathrm{Mn}$ & 0.40 & 0.67 & 0.13 & 0.05 & 0.02 & 0.02 & 0.03 & 0.90 & 0.12 & 0.07 & 0.56 \\
\hline $\mathrm{Cu}$ & 1.36 & 0.01 & 0.05 & 0.15 & 0.16 & 0.01 & 0.18 & 0.01 & 0.06 & 0.01 & 0.08 \\
\hline Y & 0.12 & 0.07 & 0.02 & 0.02 & 0.02 & 0.02 & 0.01 & 0.06 & 0.03 & 0.05 & 0.04 \\
\hline $\mathrm{Zr}$ & 0.08 & 0.05 & 0.02 & 0.02 & 0.02 & 0.02 & 0.01 & 0.05 & 0.04 & 0.05 & 0.04 \\
\hline $\mathrm{Ce}$ & 0.10 & 0.08 & 0.03 & 0.03 & 0.03 & 0.03 & 0.03 & 0.06 & 0.04 & 0.04 & 0.05 \\
\hline \multicolumn{12}{|c|}{ Group 3} \\
\hline Co & 0.03 & 0.02 & 0.02 & 0.03 & 0.03 & 0.03 & 0.03 & 0.02 & 0.02 & 0.01 & 0.02 \\
\hline $\mathrm{Ni}$ & 0.21 & 0.05 & 0.06 & 0.04 & 0.07 & 0.08 & 0.06 & 0.11 & 0.18 & 0.22 & 0.08 \\
\hline $\mathrm{Zn}$ & 1.2 & 1.6 & 1.7 & 1.8 & 1.7 & 1.5 & 1.7 & 1.6 & 1.6 & 1.6 & 1.7 \\
\hline $\mathrm{Ga}$ & 0.03 & 0.04 & 0.05 & 0.03 & 0.04 & 0.05 & 0.04 & 0.03 & 0.04 & 0.03 & 0.04 \\
\hline $\mathrm{Ge}$ & 0.2 & 0.17 & 0.13 & 0.21 & 0.18 & 0.15 & 0.16 & 0.19 & 0.22 & 0.21 & 0.16 \\
\hline As & 0.08 & 0.06 & 0.14 & 0.04 & 0.15 & 0.1 & 0.15 & 0.16 & 0.08 & 0.05 & 0.04 \\
\hline $\mathrm{Se}$ & 1.5 & 1.2 & 2.5 & 3.8 & 3.3 & 3.5 & 2.1 & 0.8 & 0.4 & 1.8 & 1.8 \\
\hline $\mathrm{Rb}$ & 0.14 & 0.08 & 0.1 & 0.07 & 0.1 & 0.17 & 0.09 & 0.12 & 0.28 & 0.2 & 0.14 \\
\hline $\mathrm{Be}$ & 0.002 & 0.002 & 0.01 & 0.008 & 0.016 & 0.004 & 0.014 & 0.008 & 0.004 & 0.004 & 0.010 \\
\hline Mo & 0.07 & 0.11 & 0.65 & 0.1 & 0.19 & 0.39 & 0.13 & 0.08 & 0.23 & 0.11 & 0.13 \\
\hline $\mathrm{Ba}$ & 12.2 & 11.9 & 12.6 & 12.2 & 14 & 12.5 & 13.7 & 11.9 & 14.2 & 11.8 & 10.7 \\
\hline $\mathrm{Pb}$ & 0.1 & 0.13 & 0.13 & 0.14 & 0.14 & 0.13 & 0.14 & 0.13 & 0.13 & 0.13 & 0.14 \\
\hline
\end{tabular}

Note: 1) sampling points in the Vishera River are highlighted in bold; 2) sampling points in the table are arranged in the order of the route down the Vishera River. 

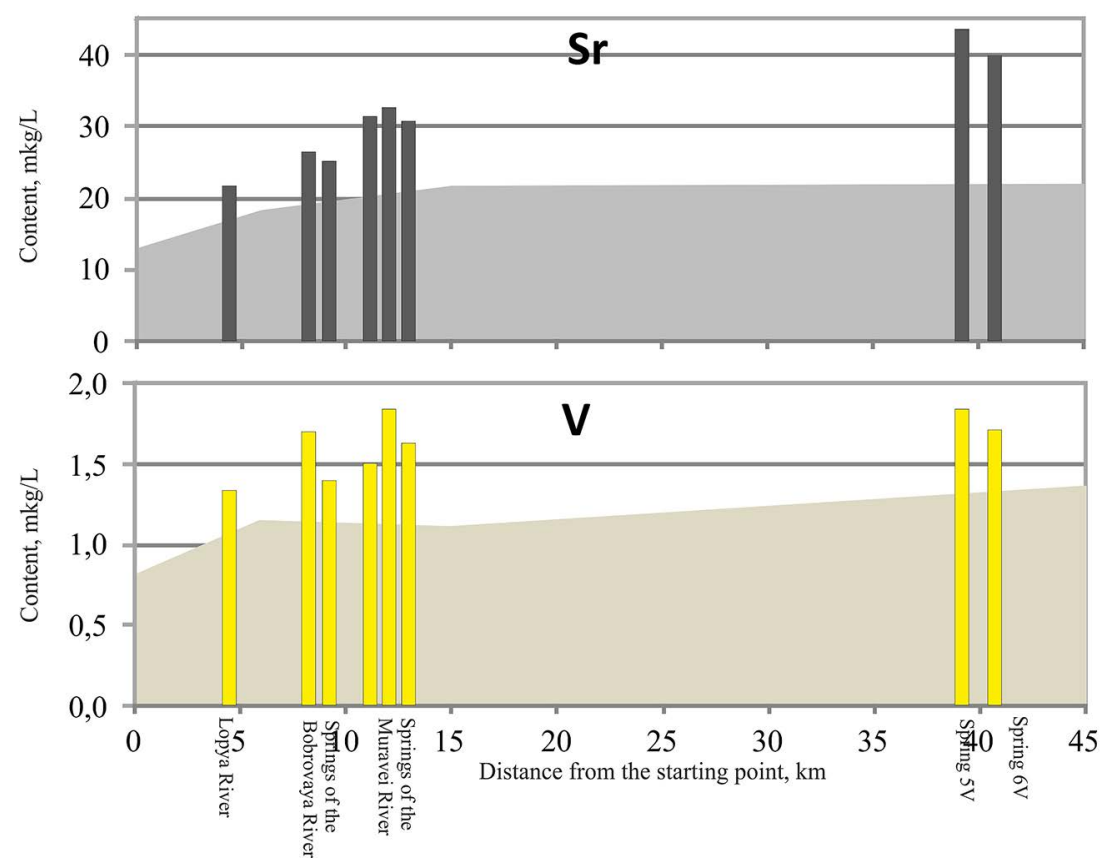

Figure 6. Strontium and vanadium concentrations in the waters of the Vishera River and the waters of karst springs
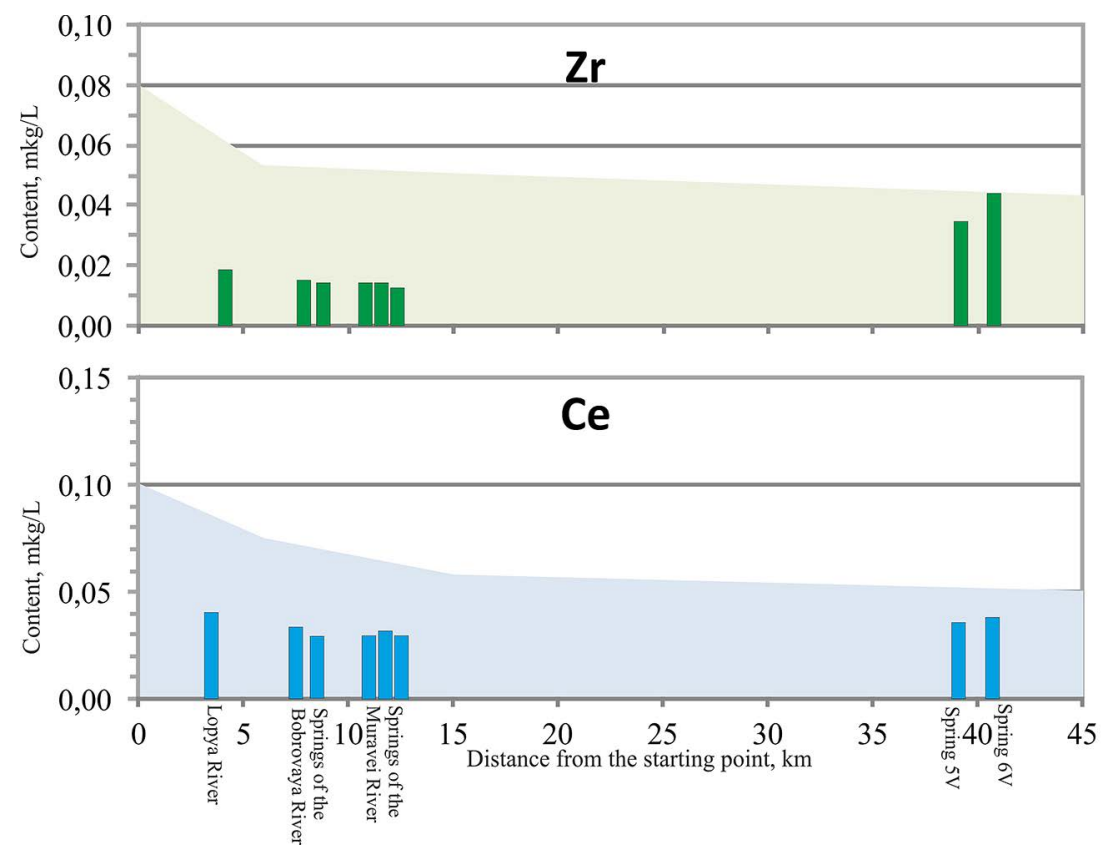

Figure 7. Concentrations of zirconium and cerium in waters of the Vishera River and waters of karst springs

\section{CONCLUSIONS}

The study of the properties and composition of ground and surface waters in the 46-km section in the upper streams of the Vishera river has shown that the powerful discharge of subaquatic karst springs plays a significant role in the formation of the river flow. The contribution of the largest springs to the formation of the river flow is $22-36 \%$ of the total flow of the Vishera river.
A significant component of the underground feeding of the river leads to a decrease in the temperature of the river water by several degrees in the areas located downstream from the springs.

Due to the powerful subaquatic discharge of karst waters, significant changes in the chemical composition of the Vishera river water are observed. The hydrogen content increases from neutral values in the upper part of the section downstream to slightly alkaline values. Mineralization 
increases from 22 to $67 \mathrm{mg} / \mathrm{l}$ primarily due to increased content of hydrocarbonate ions and calcium ions. Downstream in the investigated section, the concentrations of alkaline earth metals as well as $\mathrm{V}$ and $\mathrm{Cr}$ increase in the river water. In contrast, the concentrations of $\mathrm{Al}, \mathrm{Ti}, \mathrm{Mn}, \mathrm{Cu}, \mathrm{Y}$, $\mathrm{Zr}$, and Ce decrease.

Such changes in the chemical composition are associated both with the features of the chemical composition of karst carbonate rocks, due to the dissolution of which the composition of groundwater is formed, and with the conditions of migration of chemical elements in the studied area of the Vishera river. The results obtained significantly complement and extend the knowledge of hydrogeological, hydrological and hydrogeochemical features of the territory of the "Vishersky" reserve. At the same time, the results of the study show that monitoring the composition and properties of groundwater discharged covertly in the river channel constitute an important part of the monitoring of water bodies of both protected and developed areas.

\section{Acknowledgements}

The research was supported by the Perm Research and Education Centre for Rational Use of Subsoil, 2021.

\section{REFERENCES}

1. Afgane R., Benjelloun F., Lahrach A., Daide F. 2021. Comparative Study of the Physico-Chemical and Metallic Quality of Waters and Sediments in the Larbaa Basin (Morocco) in the Dry and Wet Period. J. Ecol. Eng., 22(8), 92-102. DOI: $10.12911 / 22998993 / 140261$

2. Blinov S.M., Khmurchik V.T., Abdullin S.R., Shchukova I.V. 2008. The complex study of subaqual karsyic water sources of "Visherskiy" Reserve. Bulletin of Perm University. Geology, 10, 111-123.

3. Blinov S.M., Lavrov I.A., Tyurina I.M. 2004. Study of subaquatic karst springs. Proc. Karst Science XXI Century: Proceedings of the International Symposium on Karst, 176-178.

4. Blinov S.M., Shchukova I.V., Baturin E.N. 2010. Subaqueous karst springs of the Permian Urals: basics of classification. Natural and technical sciences, 6(50), 287-291.

5. Cantú Medina F.G., Ventura-Houle R., Heyer Rodríguez L., et al. 2021. Water-rock interactions in a karst aquifer located in southwestern Tamaulipas, Mexico. Carbonates and Evaporites, 36(3), 59. DOI: 10.1007/s13146-021-00723-8

6. Davybida L., Kasiyanchuk D., Shtohryn L., et al. 2018. Hydrogeological Conditions and Natural Factors Forming the Regime of Groundwater Levels in the Ivano-Frankivsk Region (Ukraine). J. Ecol. Eng., 19(6), 34-44. DOI: 10.12911/22998993/91883

7. Dublyansky V.N., Dublyanskaya G.N., Karstology. Perm State University, Perm.

8. Gonneea M.E., Charette Matthew A., Liu Q., et al. 2014. Trace element geochemistry of groundwater in a karst subterranean estuary (Yucatan Peninsula, Mexico). Geochimica et Cosmochimica Acta, 132, 31-49. DOI: 10.1016/j.gca.2014.01.037

9. Maksimovich G.A. Fundamentals of Karstology. 1963. Perm State University, Perm.

10. Mustafa O., Tichomirowa M., Kummer N.A., et al. 2016. Assessment of water-rock interaction processes in the Karst Springs of Makook Anticline (Kurdistan Region, Iraq) using Sr-isotopes, rare earth, and trace elements. Arabian Journal of Geosciences, 9, 368. DOI: 10.1007/s12517-016-2344-7

11. Naoura J., El Kati I., Benaabidate L. 2021. Assessment of Ras El Ma Karst Spring Features by Structural and Functional Approaches at the Region of Taza, Morocco. J. Ecol. Eng., 22(9), 32-47. DOI: 10.12911/22998993/141477

12. Pratama A.D., Dwiputra D.S., Nurkholis A., et al. 2021. Factors Affecting Hydrochemistry of Karst Springs and their Relationship to Aquifer Development. Environmental Processes, 8, 13791413. DOI: $10.1007 / s 40710-021-00547-7$.

13. Savatier M., Rocha C. 2021. Rethinking tracerbased ( $\mathrm{Ra}, \mathrm{Rn}$, salinity) approaches to estimate point-source submarine groundwater discharge (SGD) into coastal systems. Journal of Hydrology, 598. DOI: 10.1016/j.jhydrol.2021.126247

14. Schubert M., Scholten J., Schmidt A., Comanducci J.F., Pham M.K., Mallast U., Knoeller K. 2014. Submarine Groundwater Discharge at a Single Spot Location: Evaluation of Different Detection Approaches. Water, 6(3), 584-601. DOI: 10.3390/ w6030584

15. Sklyarov E.V., Gladkochub D.P., Donskaya T.V. 2001. Interpretation of geochemical data. Intermetengineering, Moscow.

16. Stevanović Z., Pekaš Ž., Stevanović A.M., Eftimi R., Radulović M. 2022. Springs as Essential Water Sources for Dependent Ecosystems in Karst. In book: Small Water Bodies of the Western Balkans. Springer Water, 1-20. DOI: 10.1007/978-3-030-86478-1_1.

17. Stevanović Z. 2019. Karst waters in potable water supply: a global scale overview. Environmental Earth Sciences, 78, 662. DOI: 10.1007/ 
s12665-019-8670-9.

18. Tamborski J., van Beek P., Conan P., Pujo-Pay M., et al. 2020. Submarine karstic springs as a source of nutrients and bioactive trace metals for the oligotrophic Northwest Mediterranean Sea. Science of The Total Environment, 732, 139106. DOI: 10.1016/j. scitotenv.2020.139106

19. Vaganov S.S. 2017. Experience in search and investigation of groundwater sources of karst massifs discharging from the bottom of rivers and lakes.
Natural and technical sciences, 11(113), 64-65.

20. Wang X., Su K., Du J. et al. 2021. Estimating submarine groundwater discharge at a subtropical river estuary along the Beibu Gulf, China. Acta Oceanologica Sinica, 40, 13-22. DOI: 10.1007/ s13131-021-1862-7.

21. Wirth Stefanie B., Bouffard Damien, Zopfi Jakob. 2020. Lacustrine Groundwater Discharge Through Giant Pockmarks (Lake Neuchatel, Switzerland). Front. Water. DOI: 10.3389/frwa.2020.00013. 